\begin{tabular}{|l|c|c|c|r|}
\hline $\begin{array}{l}\text { Cuadernos de Investigación Geográfica } \\
\text { Geographical Research Letters }\end{array}$ & 2018 & No $^{\circ} 44(2)$ & pp. 429-452 & $\begin{array}{r}\text { ISSN 0211-6820 } \\
\text { eISSN 1697-9540 }\end{array}$ \\
\hline
\end{tabular}

DOI: http://doi.org/10.18172/cig.3349

(C) Universidad de La Rioja

\title{
RUNOFF GENERATION IN A PRE-ALPINE CATCHMENT: A DISCUSSION BETWEEN A TRACER AND A SHALLOW GROUNDWATER HYDROLOGIST
}

\author{
H.J. VAN MEERVELD ${ }^{1 *}$, B.M.C. FISCHER ${ }^{1}$, \\ M. RINDERER ${ }^{2}$, M. STÄHLI ${ }^{3}$, J. SEIBERT $^{1,4}$ \\ ${ }^{1}$ Department of Geography, University of Zurich, Zurich, Switzerland. \\ ${ }^{2}$ Chair of Hydrology, University of Freiburg, Freiburg, Germany. \\ ${ }^{3}$ Swiss Federal Research Institute WSL, Birmensdorf, Switzerland. \\ ${ }^{4}$ Department of Earth Sciences, Uppsala University, Uppsala, Sweden.
}

\begin{abstract}
Runoff generation mechanisms vary between catchments and despite decades of research in many catchments, these mechanisms are still not fully understood. In this paper, runoff generation mechanisms in the steep prealpine catchments in the Alptal, Switzerland, are discussed. These fast responding catchments are characterized by low permeability soils on top offlysch bedrock. In combination with the high and frequent precipitation, this results in predominantly wet conditions. In many areas, the water table is close to the surface. We review the main results of recent (2009-2016) studies in these catchments that used isotope, stream chemistry and hydrometric data. These field studies focused on the spatial and temporal patterns in groundwater levels, spatial patterns in the isotopic composition and chemistry of streamflow during baseflow conditions, as well as the responses of streamflow and its isotopic composition during rainfall events. The combined results of these studies highlight the establishment of connectivity of areas with different topographic positions and areas with a different land use during rainfall events. They also show the importance of flow in higher conductivity near surface soil layers for runoff generation, as well as the frequent occurrence of surface runoff. Spatial differences in groundwater dynamics are related to topography. Streamflow responses are mainly affected by the rainfall characteristics; differences in streamflow and hydrochemistry between catchments with different portions of forest, meadows and wetlands, were relatively small. However, variations in the chemistry of baseflow along stream reaches within a catchment were considerable. Above all, these studies highlight the value of combining data on spatial patterns of groundwater levels and stream chemistry with long term data on streamflow to derive a more complete picture of the dominant runoff generation mechanisms.
\end{abstract}




\section{Generación de escorrentía en una cuenca pre-alpina: una discusión entre un hidrólo- go interesado en trazadores y otro interesado en aguas subterráneas poco profundas}

RESUMEN. Los mecanismos de generación de escorrentía varían entre cuencas y, a pesar de décadas de investigación en numerosas cuencas, estos mecanismos todavía no se entienden completamente. En este trabajo se discuten los mecanismos de generación de escorrentía en las cuencas pre-alpinas del Alptal, Suiza, caracterizadas por fuertes pendientes. Estas cuencas, que presentan respuestas rápidas, poseen suelos poco permeables sobre estratos de flysch. Esta composición geológica, sumada a un régimen de precipitaciones abundantes y frecuentes, se traduce en condiciones predominantemente húmedas. En muchas zonas, el nivel freático se encuentra cerca de la superficie. En este trabajo se revisan los principales resultados de varios estudios recientes (2009-2016) llevados a cabo en estas cuencas usando datos isotópicos, de química del caudal e hidrométricos. Estos estudios de campo se centraron en la investigación de los patrones espaciales y temporales de los niveles freáticos, los patrones espaciales de la composición isotópica y química del caudal en condiciones de flujo de base, así como la respuesta del caudal y su composición isotópica durante eventos pluviométricos. La combinación de los resultados de estos estudios destaca la conectividad que se establece durante eventos pluviométricos entre áreas con una posición topográfica diferente y con diferentes usos del suelo. Los resultados muestran también la importancia que tienen los flujos de agua en las capas de suelo más superficiales y con mayor conductividad para la generación de escorrentía, así como la ocurrencia frecuente de escorrentía superficial. Las diferencias espaciales en la dinámica de las aguas subterráneas están relacionadas con la topografía. La respuesta del caudal está influenciada principalmente por las características de la lluvia; las diferencias de caudal y de química del agua entre cuencas con diferentes porcentajes de cubierta forestal, prados y humedales fueron relativamente pequeñas. Sin embargo, las variaciones en la química del flujo de base en diferentes secciones del cauce en una misma cuenca fueron considerables. Ante todo, estos estudios destacan el valor de combinar datos sobre patrones espaciales de niveles freáticos y de química del agua con series largas de datos de caudal para obtener una imagen más completa de los principales mecanismos de generación de escorrentía.

Key words: runoff generation, gleysols, topography, shallow groundwater, isotopes, pre-alpine catchment.

Palabras clave: generación de escorrentía, gleysoles, topografía, aguas subterráneas poco profundas, isótopos, cuenca pre-alpina.

\footnotetext{
* Corresponding author: H.J. (Ilja) Van Meerveld, Department of Geography, University of Zurich, Winterthurerstrasse 190, CH-8057 Zurich, Switzerland. E-mail address: ilja. vanmeerveld@geo.uzh.ch
} 


\section{Introduction}

Catchment studies in Switzerland were started by the Swiss Federal Institute for Forest, Snow and Landscape Research (WSL) at the beginning of the 20th century. The first paired catchment study took place in the Emmental (Engler, 1919; Hegg et al., 2006). Research in the Alptal watershed in central Switzerland began in 1963 and focused on the effects of forestry on floods and water quality. The areas underlain by flysch (which is a geologic formation consisting of a sequence of sedimentary rocks that were deposited in a basin adjacent to a rising mountain belt) had undergone significant reforestation since the 1900s because it was thought that logging and degradation of the forests could have contributed to the large floods in 1834, 1839, 1860, and 1868 (Hegg et al., 2006; Stähli et al., 2011). The Alptal is typical for the Swiss pre-alpine region; it is characterized by frequent and high rainfall and low permeability soils, and therefore mostly wet conditions. Streams in the region respond quickly to precipitation (i.e. within minutes to an hour) but generally return to baseflow conditions within 1-2 days (Fischer et al., 2017a). Initially, streamflow was measured in eleven sub-catchments in the Alptal but after a destructive flood on 23 June 1974, research was focused on three of them (Vogelbach, Lümpenenbach, Erlenbach). The $0.73 \mathrm{~km}^{2}$ Erlenbach catchment is well known for the facilities to measure sediment transport (e.g., Rickenmann et al., 2012; Wyss et al., 2016) and is part of the National River Monitoring and Survey program (NADUF). The University of Zurich started research in the headwater catchments neighboring the Erlenbach in 2009 to (i) better understand the hydrological processes that result in the very fast runoff response and their spatiotemporal variation, and to (ii) determine the differences in the runoff response in catchments with different fractions of forest, meadows and wetlands. This research complements the existing research in the Erlenbach on snow processes (e.g., Stähli and Gustafsson, 2006; Stähli et al., 2009) and sediment (e.g., Badoux et al., 2012; Roth et al., 2016) and nutrient transport (e.g., Hagedorn et al., 2001; Schleppi et al., 2004; Providoli et al., 2006; Smith et al., 2013).

This paper builds on an earlier overview paper by Hegg et al. (2006) and reviews the main results of the measurements between 2009-2016 in the catchments neighboring the Erlenbach. In particular, this review summarizes findings of two recent $\mathrm{PhD}$ theses (Rinderer, 2015; Fischer, 2016) and six Master thesis (Kollegger, 2011; Zehnder, 2013; Herrmann, 2014; Sjöberg, 2015; Grunder, 2017; Sauter, 2017). The focus of this review is on the detailed studies in the catchment with the densest measurement network (WS07, also known as the Studibach) during the snow-free period and relates the detailed measurements in this catchment to the hydrochemistry and streamflow responses in five neighboring catchments (Fig. 1b). The results of these recent studies highlight the usefulness of both tracer and hydrometric data, as previously demonstrated in many other catchment studies (e.g., Bonell and Fritsch, 1997; Carey and Quinton, 2005; Stewart et al., 2007; Wenninger et al., 2008), and how long-term streamflow and climate data and spatially distributed measurements can complement each other to better understand the main runoff generation mechanisms and the areas that contribute to streamflow. 


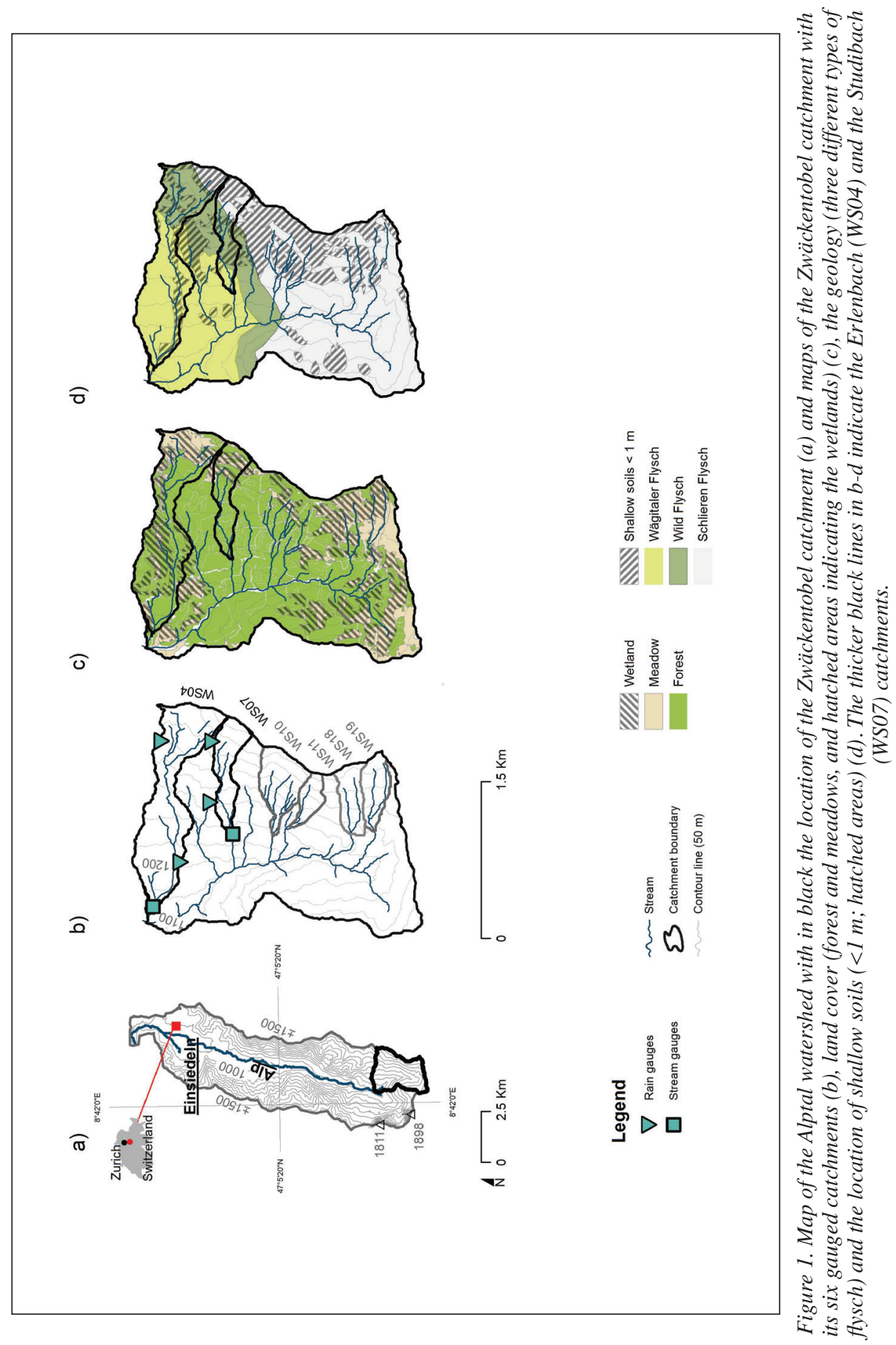




\section{Study site description}

\subsection{Location}

The Alptal is located in the Swiss pre-alpine region, approximately $40 \mathrm{~km}$ southeast from Zurich (47 02 '20'” $\mathrm{N}$ and $8^{\circ} 43^{\prime} 45^{\prime}$ 'E; Fig. 1a). The ten $\left(0.1-0.7 \mathrm{~km}^{2}\right)$ headwater catchments in the study area drain into the Zwäckentobel and range in elevation between 1084 and $1656 \mathrm{~m}$ above sea level (m a.s.l.) (Table 1). The Zwäckentobel drains into the Alp, before flowing into the Sihl, the Limmat, the Aare and ultimately the Rhine.

Table 1. Characteristics of the catchments (see Fig. $1 \mathrm{~b}$ for the location of the study catchments and Fig. 1c for the land use map).

\begin{tabular}{|l|l|l|l|}
\hline & $\begin{array}{c}\text { Studibach } \\
\text { (WS07) }\end{array}$ & $\begin{array}{c}\text { Erlenbach } \\
\text { (WS04) }\end{array}$ & $\begin{array}{c}\text { Zwäckentobel } \\
\text { catchment }\end{array}$ \\
\hline Area $\left(\mathbf{k m}^{2}\right.$ ) & 0.2 & 0.7 & 4.3 \\
Elevation range (m a.s.l.) & $1270-1650$ & $1109-1656$ & $1084-1656$ \\
Average (max) slope $\left(^{\circ}\right)$ & $21(47)$ & $17(49)$ & $19(56)$ \\
Forest cover $(\%)$ & 53 & 53 & 55 \\
Wetland cover $(\%)$ & 28 & 33 & 29 \\
Shallow soils $(<\mathbf{1 m} ; \%) *$ & 55 & 44 & 29 \\
\hline
\end{tabular}

"based on Fischer et al. (2015).

\subsection{Topography}

The headwater catchments in the Alptal are steep, with an average slope of $\sim 19^{\circ}(35 \%)$. The topography is influenced by soil creep and landslides (Fig. 2b), resulting in a complex terrain with alternating steeper and gentler slopes. There is also distinct surface micro-topography, e.g. hummocks and hollows in the flatter wetland areas. The drainage density is high $\left(21 \mathrm{~km} \mathrm{~km}^{-2}\right.$, based on the channel network that was mapped in the Erlenbach (WS04) during baseflow conditions but this does not include many of the small ephemeral streams). The flowing stream drainage density in the upper parts of WS04, WS07, WS18 and WS19 increased by a factor of five between the very dry conditions at the end of August 2016 and the first rainfall events in fall 2016 (Sjöberg, 2015). The channels have a step-pool morphology (Molnar et al., 2010) and cut into the alluvium of weathered bedrock (Keller, 1970). However, most of the streams are relatively shallow and only the larger streams are incised by more than $0.5 \mathrm{~m}$ (Figs. $2 \mathrm{~d}$ and $2 \mathrm{e}$ ). The headwater streams have almost no riparian zone. 

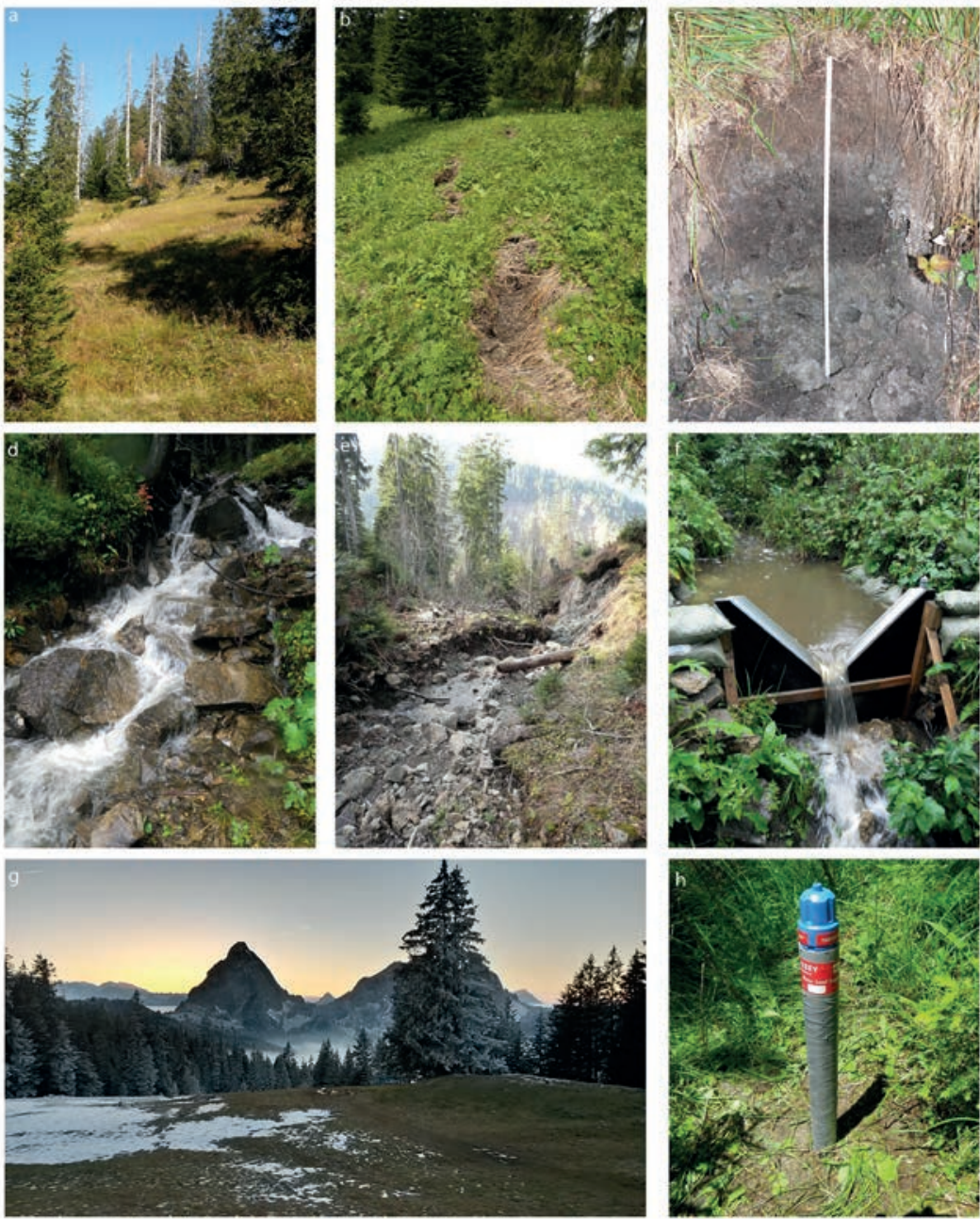

Figure 2. Photos from the Alptal showing the open forest (a), evidence of shallow landsliding ( $b$ ), a soil profile of the gleysol (c), streams (d-e), a v-notch weir in the Studibach (WSO7)(f), the view from the upper part of the catchment to the neighbouring mountains (Mythen) $(g)$ and one of the groundwater wells $(h)$. All figures by M. Rinderer, except for figure $g$, which was taken by Rick Assendelft (University of Zurich).

\subsection{Climate}

The Alptal has a humid temperate climate and is characterized by frequent rainfall (Fig. 3). The mean annual temperature is $6^{\circ} \mathrm{C}$; average monthly temperatures vary from $-1^{\circ} \mathrm{C}$ in January to $14^{\circ} \mathrm{C}$ in July (Schleppi et al., 1998). The precipitation distribution 
in the Alptal valley has a distinct north-south gradient: the mean annual precipitation in the Erlenbach is $2300 \mathrm{~mm} \mathrm{y}^{-1}$ (1980-2011 data), which is $30 \%$ more than the mean annual precipitation in Einsiedeln (10 km away, $1791 \mathrm{~mm} \mathrm{y}^{-1}, 1981-2010$ data from MeteoSchweiz) and more than twice as much as the mean annual rainfall in Zurich (40 km away, $1134 \mathrm{~mm} \mathrm{y}^{-1}$, 1981-2010 data from MeteoSchweiz). Rainfall measurements by Fischer et al. (2017b) across the Zwäckentobel headwater catchments and comparisons of precipitation data from the Vogelbach, Lümpenenbach and Erlenbach show that event based rainfall amounts vary significantly throughout the study area but that there is no clear relation between event total rainfall and elevation. This is attributed to the high variability in topography and the nearby mountains (Fig. 2g) that affect local atmospheric circulation. The dominant moisture sources in the Alptal come from the North Atlantic Ocean and Central Europe (Sodemann and Zubler, 2010) but even if an event has a dominant westerly trajectory from the North Atlantic, the rainfall may approach the catchment from the eastern direction (Fischer et al., 2017b).

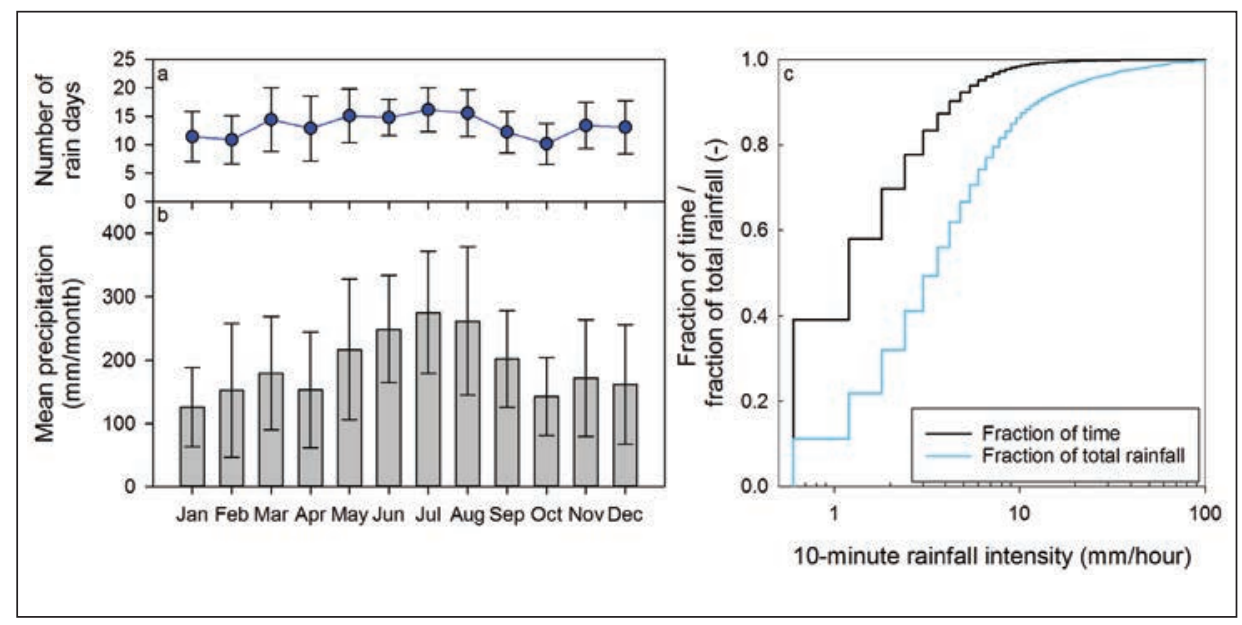

Figure 3. Mean number of rain days $\left(>1 \mathrm{~mm} \mathrm{~d}^{-1}\right)(a)$, mean monthly precipitation $(b)$ and the fraction of time that the 10-min precipitation intensity was equal to or lower than a certain intensity, and the fraction of the total precipitation that fell at an intensity equal to or lower than that intensity (c) for the 1998-2011 period. The error bars indicate the standard deviation.

Summer months are wetter than autumn and winter months (Fig. 3b). On average, it rains $\left(>1 \mathrm{~mm} \mathrm{~d}^{-1}\right)$ every second day in the summer and a little bit less frequent in winter (Fig. 3a). Most of the precipitation occurs at a low intensity. The 10 -minute precipitation intensity is more than $3 \mathrm{~mm} \mathrm{~h}^{-1}$ for only $17 \%$ of the time that it rains and more than $6 \mathrm{~mm} \mathrm{~h}^{-1}$ for $5 \%$ of the time that it rains. However, precipitation falling at intensities larger than 3 and $6 \mathrm{~mm} \mathrm{~h}^{-1}$ delivers 51 and $26 \%$ of the total precipitation, respectively (Fig. 3c).

Roughly one third of the annual precipitation falls as snow (Stähli and Gustafsson, 2006). The area is generally snow-covered from December to March, 
though snowfall often starts in November and the higher areas are often still snowcovered in May. Even during summer rainfall events, the temperatures can decrease below $0^{\circ} \mathrm{C}$ and result in snowfall. However, due to the high soil surface temperatures, the snow melts quickly and contributes to streamflow with only a short delay. With lower air temperatures in fall, the snow cover can persist longer. The amount of snow and the duration of snow cover declined significantly during the 1976 to 1993 period (Burch, 1994) and April streamflow in the Erlenbach has decreased as a result of this reduction in snow and earlier melt.

Mean annual runoff in the Erlenbach is $1800 \mathrm{~mm} \mathrm{y}^{-1}$, resulting in an estimated mean annual evapotranspiration loss of $500 \mathrm{~mm} \mathrm{y}^{-1}$. Measured streamflow in the Erlenbach varies between 3-15,000 1 s-1, which corresponds to 4-20,500 $1 \mathrm{~s}^{-1} \mathrm{~km}^{-2}$; runoff ratios tend to increase with total rainfall in a power law-like relation (Burch et al., 1996).

\subsection{Vegetation}

The study area consists of forests, open forests, meadows and wetlands (Figs. 1c and 2a; Table 1). The forested sites are generally located on the steeper slopes. Wetlands have formed in the flatter areas and contain a thick organic soil horizon (up to $1 \mathrm{~m}$ thickness). The forest is dominated by spruce trees (Picea abies L.) and Silver fir (Abies alba) with an understory of blueberries (Vaccinium sp.) on the drier sites and ferns and Equisetum on the wetter sites (Feyen, 1998; Hagedorn et al., 2000). In the lower elevations, the forest also contains maple and beech trees. The meadows contain Poa trivialis and Carex ferruginea; the wetland sites contain Caltha palustris, Petasites albus, Poa trivialis and Carex ferruginea (Hagedorn et al., 2000). The meadows in the upper parts of catchments WS04, WS07, WS18 and WS19 (>1400 m a.s.1.) are used as summer pastures. There are ski slopes in catchment WS19.

\subsection{Geology and Soils}

The study catchments are underlain by Tertiary Flysch (Fig. 1d), a sequence of sedimentary rocks, particularly argillite and bentonite schists, calcareous schists, marl and sandstone (Schleppi et al., 1998; Mohn et al., 2000). Most sub-catchments comprise of the Schlieren, Wild- and Wägitaler-Flysch (Fig. 1d) (Hantke, 1967; Hsü and Briegel, 1991). The bedrock is considered to be (relatively) impermeable (Smith et al., 2013).

The soils in the flatter areas, where the watertable is close to the soil surface and wetlands have formed, are mollic Gleysols with typically a permanently reduced $\mathrm{B}_{\mathrm{g}}$ horizon (Fig. 2c). At the steeper ridge locations, the soils are classified as umbric Gleysols with an oxidized $\mathrm{B}_{\mathrm{w}}$ horizon (Schleppi et al., 1998; Hagedorn et al., 2000). The humus layer consists of mor humus on dry ridges and muck humus in the wetter and flatter areas. Soils with mor humus are generally better structured than those with muck humus because of vertical micro-structures formed by stones and tree roots (Feyen, 1998). Soil depth varies from $0.5-1 \mathrm{~m}$ at the ridge sites to $2.5 \mathrm{~m}$ in depressions and is weakly related to slope (Fig. 4). 


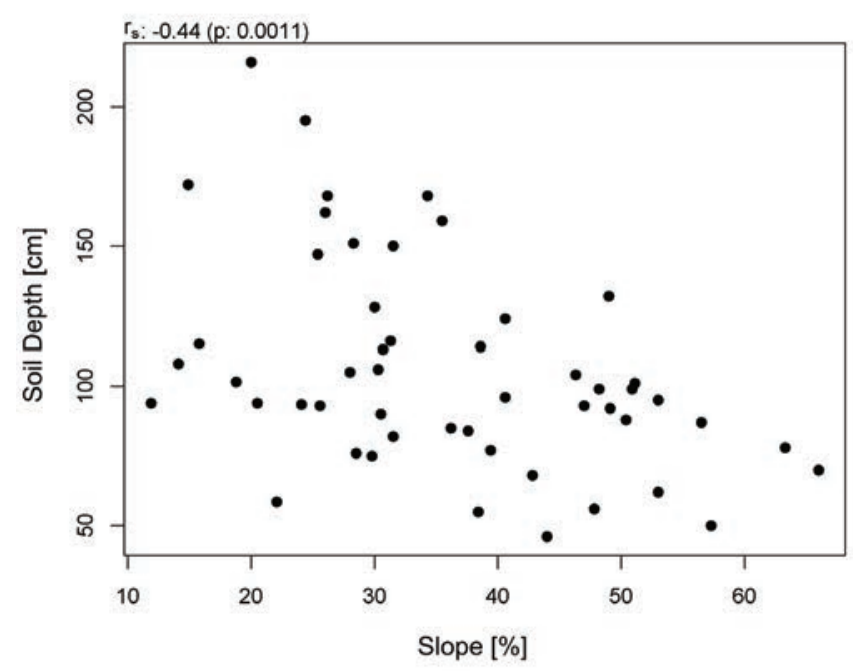

Figure 4. Relation between soil depth and local slope for the 51 groundwater monitoring sites in the Studibach (WSO7) for which soil depth was determined during well installation.

The high clay and silt content of the soils (43\% clay and $42 \%$ silt for the mollic Gleysols and $49 \%$ clay and $46 \%$ silt for the umbric Gleysols; Schleppi et al., 1998) results in a low hydraulic conductivity. However, roots significantly increase the hydraulic conductivity of the near surface layer in the forest areas. Large $(32 \mathrm{~cm}$ inner diameter) double ring infiltrometer measurements suggest a surface saturated hydraulic conductivity of 1-2 $\mathrm{mm} \mathrm{h}^{-1}$ for the wetland sites $(n=2), 2-40 \mathrm{~mm} \mathrm{~h}^{-1}$ for a steep meadow site $(n=2)$ and $>400 \mathrm{~mm} \mathrm{~h}^{-1}$ in the forest $(n=1)$ (Sauter, 2017). The saturated hydraulic conductivity at the soil-bedrock interface was determined with slug tests in 51 wells and varied from $0.1 \mathrm{~mm} \mathrm{~h}^{-1}$ to $58 \mathrm{~mm} \mathrm{~h}^{-1}$ (median: $0.4 \mathrm{~mm} \mathrm{~h}^{-1}$ ) (Zehnder, 2013). There was no clear relation between the saturated hydraulic conductivity at the soil-bedrock interface and either topography or land use (Zehnder, 2013).

\section{Main field measurements}

The streamflow, weather and sediment transport measurement systems in the Erlenbach (WS04) catchment are described in detail in Rickenmann et al. (2012). Here we focus on the additional measurements by the University of Zurich in the Studibach and the neighbouring catchments.

Rainfall has been measured in the Studibach (Fig. 5) during the summer months since 2010 (although there are data gaps for 2012-2013 and in 2015). Fischer et al. (2017b) measured rainfall and the isotopic composition of rainfall at 13 additional locations throughout the Zwäckentobel catchment for 13 rainfall events in the snow-free period of 2010 and 2011. 


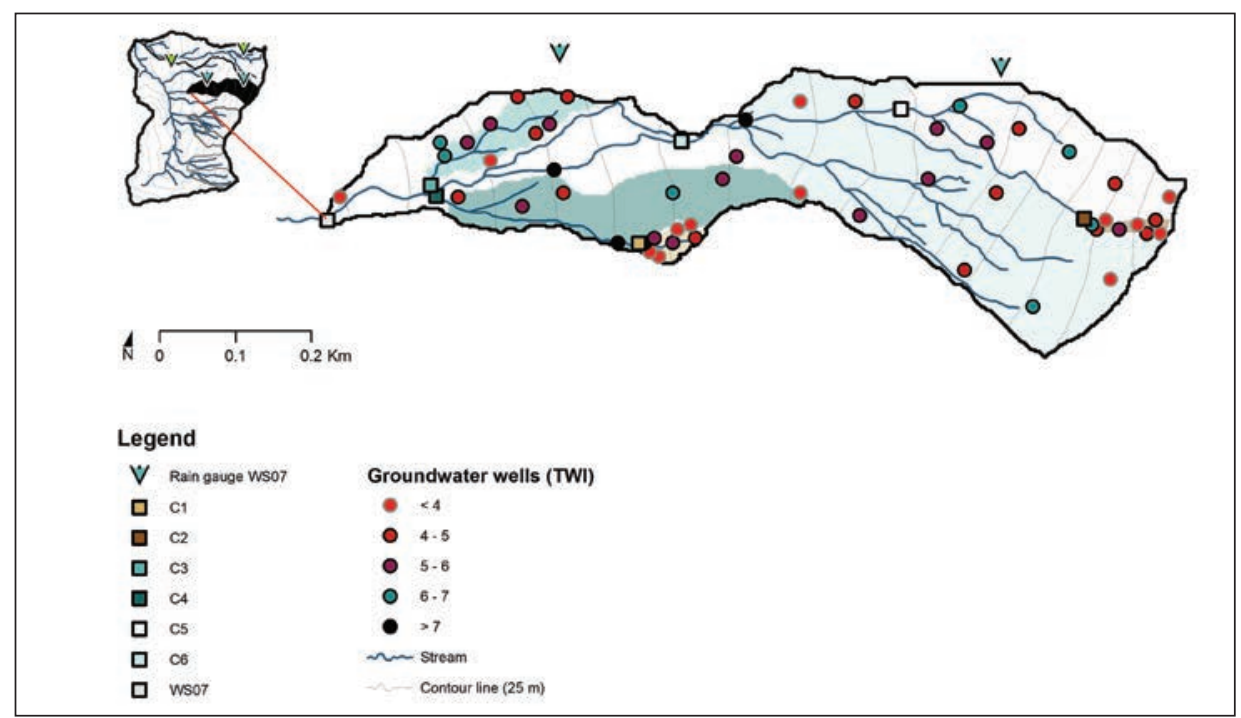

Figure 5. The Studibach (WSO7) catchment (20 ha), the six nested sub-catchments (C1: 0.2 ha to C6: $12 \mathrm{ha}$ ) and the location of the 51 groundwater monitoring wells. The colours of the wells (circles) represent the Topographic Wetness Index of the site. The gauging stations are indicated by squares.

Stream stage has been measured at the outlet of the Zwäckentobel (WS01) and five sub-catchments (WS07, WS10, WS11, WS18 and WS19; see Fig. 1b for their location) since 2009-2010 using a combination of pressure transducers and capacitance water level loggers. Due to the changing stream geomorphology, it is very difficult to derive a rating curve for these catchments. Streamflow is measured at seven locations in the Studibach using flumes (for the 0.23 ha and 0.25 ha sub-catchment), v-notch weirs (for the 1.0 ha, 3.2 ha and 3.9 ha sub-catchment; Fig. 2f) and at a natural cross-section (incised into the bedrock) for the 12 ha sub-catchment and the catchment outlet (20 ha; WS07) (Fig. 5). A rating curve was established for each of the Studibach gauging stations using salt dilution gauging (see Rinderer et al. (2014) for a more detailed description of the streamflow measurements). The dry and flowing stream network in the upper parts of WS04, WS07, WS18 and WS19 were mapped using field observations (and topographic maps and aerial photos for orientation) during the late summer and early fall of 2015 (Sjöberg, 2015).

Fifty one wells were installed to depth of refusal in the Studibach in 2009 and 2010 and water levels have been continuously measured using a combination of pressure transducers and capacitance sensors (Figs. $2 \mathrm{~h}$ and 5). The wells are located across the entire catchment; locations were chosen based on the frequency distribution of the Topographic Wetness Index (TWI; defined as: $\ln (a / \tan \beta)$, where $a$ is the upslope contributing area per unit contour length $[\mathrm{m}]$ and $\beta$ is the local slope $\left[{ }^{\circ}\right]$ ) (Beven and Kirkby, 1979) in each of the seven sub-catchments. This ensured a network of wells that is representative for the different landscape positions and morphological units. For more details on the groundwater measurement network, see Rinderer et al. (2014; 2016). 
Surface soil moisture (0-16 cm depth) was measured weekly at 100 sites in seven 0.1-5 ha plots in the Erlenbach catchment between 29.07.2010 and 29.09.2010. Soil moisture measurements were taken with a TRIME-PICO 64 TDR sensor at five locations per site and then averaged for each site (Kollegger, 2011).

Fifty surface runoff collectors were installed in the Studibach in summer 2016 and emptied after each rainfall event in summer and fall 2016 (Sauter, 2017). The surface runoff collectors were modeled after Zimmerman et al. (2014) and consist of a $500 \mathrm{~mm}$ pipe with two rows of holes to collect overland flow and a pipe junction to store the water. The collectors were installed at three wetland sites, three meadow sites, three bareland sites and two forest sites (five collectors per site, except for the forest sites where only three collectors were installed per site).

Streamwater, springs and groundwater were sampled at more than 80 sampling locations throughout the Zwäckentobel sub-catchments during baseflow conditions in 2010 and 2011 (Fischer et al., 2015). The samples were analysed for their isotopic composition, alkalinity, $\mathrm{pH}$, and calcium (Ca), dissolved organic carbon (DOC), sulphate, magnesium and silica concentrations. In summer 2016, additional streamflow samples were taken along two stream sections in the Studibach (C3 and C5; see Fig. 5) (Grunder, 2017). Streamflow samples were also taken during thirteen rainfall-runoff events during the snow free seasons of 2010 and 2011 in WS04, WS07, WS10, WS18 and WS19. The events covered a wide range of rainfall event sizes and antecedent wetness conditions (Fischer et al., 2017a).

\section{Hydrometric results}

\subsection{Streamflow}

Streamflow at the gauging stations in the Studibach (WS07) (Fig. 5) responds within tens of minutes to rainfall. The range (for the Studibach and its six sub-catchments) of the median lag time between the start of precipitation and the start of the rise in stream level for 25 events in 2013 was 25-100 min (median: $70 \mathrm{~min}$ ) (Herrmann, 2014). The median response time and the variability in response timing during this period did not change systematically with catchment area and was also not correlated to other topographic indices (Herrmann, 2014).

The event runoff coefficients, defined as the ratio between total event stormflow and total event precipitation, were generally high; the 25 th and 75 th percentile were 8 and $30 \%$ (median: $16 \%)$ for the 0.25 ha sub-catchment $(\mathrm{C} 2 ; 210$ rainfall events between 2010 and 2014) and 10 and 53\% (median: 30\%) for the 20 ha Studibach catchment (WS7; 175 rainfall events between 2010 and 2014). The median runoff coefficients for the Studibach and its six sub-catchments were significantly correlated with the mean slope of the upslope contributing area $\left(r_{s}=-0.96\right)$ but not with other topographic indices. However, the median specific discharge for the gauging stations in the Studibach $(\mathrm{n}=$ 7) was correlated to the upslope contributing area $\left(r_{s}=0.82\right)$, the TWI $\left(r_{s}=0.82\right)$ and the mean TWI of the upslope contributing area $\left(r_{s}=0.86\right)$. 


\subsection{Soil moisture}

Even though the study area is generally wet, there are large differences in soil moisture conditions. Weekly soil moisture measurements during the summer of 2010 showed that the spatial variability in soil moisture was larger than the temporal variability (Kollegger, 2011). Soil moisture was significantly higher in the open areas (average soil moisture between 58 and 67\%) than the forested sites (average between 45 and 52\%). Even though soil moisture was higher in the hollows than on the ridges, and higher on concave slopes than convex areas, the correlation between measured surface soil moisture and the TWI was low $\left(r^{2}=0.20\right)$ (Kollegger, 2011).

\subsection{Groundwater}

Groundwater levels in the Studibach responded frequently to rainfall events and were most variable at mid-slope locations (Rinderer et al., 2016). The median response frequency of all groundwater monitoring sites for rainfall events between 2010 and 2014 was $84 \%$ (Rinderer et al., 2014). Water levels tended to be high at sites with a larger TWI and fluctuated more at sites with a lower TWI; the recession was faster for sites with a lower TWI (Fig. 6). The median relative to soil depth groundwater levels for the 2010-2014 period and the skewness of the frequency distributions of groundwater levels were correlated with topographic indices. For example, median relative groundwater levels were correlated to local slope (Spearman rank correlation $r_{s}=-0.67$ ), upslope contributing area $\left(\mathrm{r}_{\mathrm{s}}=0.69\right)$ and TWI $\left(\mathrm{r}_{\mathrm{s}}=0.78\right)$ (Rinderer et al., 2014). In contrast, median relative groundwater levels were not significantly correlated with soil depth or the saturated hydraulic conductivity of the mineral soil at the soil-bedrock interface.

For the 2010-2014 period studied by Rinderer et al. (2014), the correlation between groundwater levels and TWI decreased at the beginning of rainfall events when groundwater levels responded differently across the catchment and was lowest shortly after peak streamflow. During the falling limb of the hydrograph, when the groundwater levels started to decline in all parts of the catchment, the correlation between groundwater level and TWI increased quickly and was generally highest twelve hours to two days after the event (Rinderer et al., 2014). During long dry periods, when some groundwater wells went dry and parts of the upslope contributing area became disconnected, the correlation between groundwater levels and topographic indices gradually decreased again (Rinderer et al., 2014).

The correlation between median groundwater levels and topographic indices also varied seasonally and was lowest $\left(\min r_{s}=0.54\right)$ during the dormant season when groundwater levels were predominantly low, and highest $\left(\max r_{s}=0.88\right)$ during spring when the groundwater levels were close to the soil surface. However, the highest correlations were obtained when changes in streamflow and groundwater levels were smallest (Rinderer et al., 2014).

The time to rise (the time between the start of a rainfall event and the first response of the groundwater level in a well) was generally less than 30 minutes. The median time to rise was dependent on the amount of rainfall during this period $\left(r_{s}=0.98\right)$ and was 
correlated to topographic indices, such as TWI $\left(r_{s}=-0.81\right)$, upslope contributing area $\left(r_{s}=-0.74\right)$ and local slope $\left(r_{s}=0.64\right)$ (Rinderer et al., 2016). The median time to rise decreased with increasing TWI for sites with a TWI $<6$ and was almost constant for all other sites. The slope of the decline of median time to rise with TWI was a function of rainfall intensity. The relation between time to rise and TWI allowed identification of zones of potential groundwater response as a function of rainfall (Rinderer et al., 2016). Groundwater peaks lagged rainfall centroids by about one hour for half of the rainfall events but the median groundwater peak lag time was not correlated to any of the topographic indices (Rinderer et al., 2016).

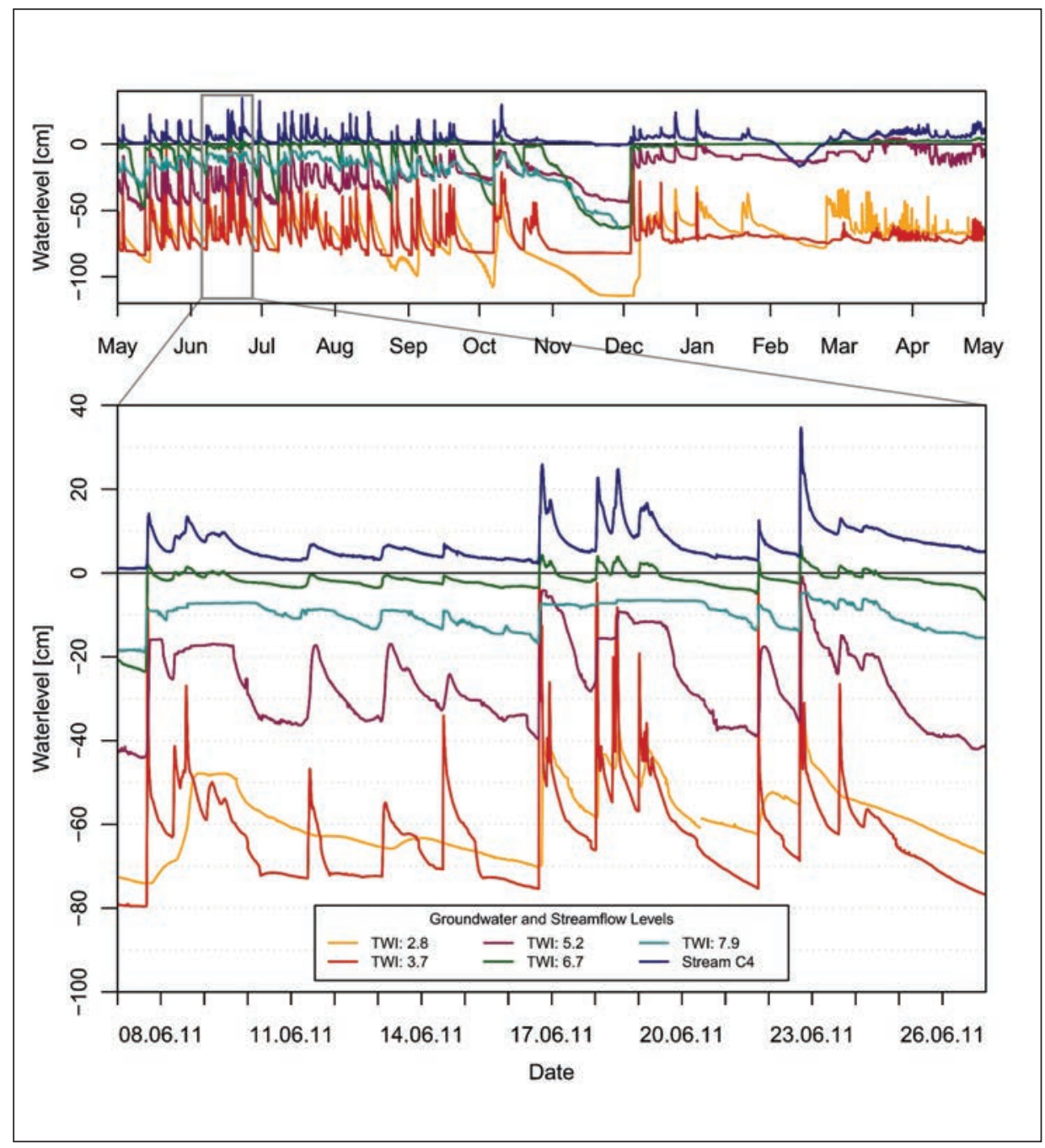

Figure 6. Time series of groundwater levels at selected monitoring sites with a different Topographic Wetness Index (TWI) in the Studibach and stream-stage (C4 in WSO7) for May 2011-2012 (top row) and June 2011 (bottom row). 
Similarity in groundwater and streamflow dynamics was determined using time series clustering. Distance-based similarity measures based on the integral between two time series capture similarity in the shape and amplitude of the time series and were correlated with topographic indices. Correlation-based similarity measures (based on the cross-correlation of two time series) revealed seasonal differences in the similarity in groundwater and streamflow time series (Rinderer et al., 2017). The cross-correlation between groundwater and streamflow time series was higher during the growing season than during the dormant season, suggesting a stronger coupling of groundwater and streamflow and most likely a higher degree of connectivity between hillslopes and streams during the growing season than during the dormant season (Rinderer et al., 2017).

\subsection{Surface runoff}

During rainfall events, surface runoff occurred often on the meadows, wetlands and at bare soil locations but infrequently at the forested sites (Fig. 7). The number of locations where surface runoff was detected increased with event size and maximum rainfall intensity (Sauter, 2017). The chemical composition of surface runoff was highly variable and represented soil water and groundwater more than the rainwater, except on the bare land sites where its isotopic composition reflected the rainfall but the water was enriched in calcium (Sauter, 2017). Saturated overland flow (rather than infiltration overland flow) seemed to be the main surface runoff mechanism, except on the bare lands, where infiltration-excess overland flow is likely (Sauter, 2017).

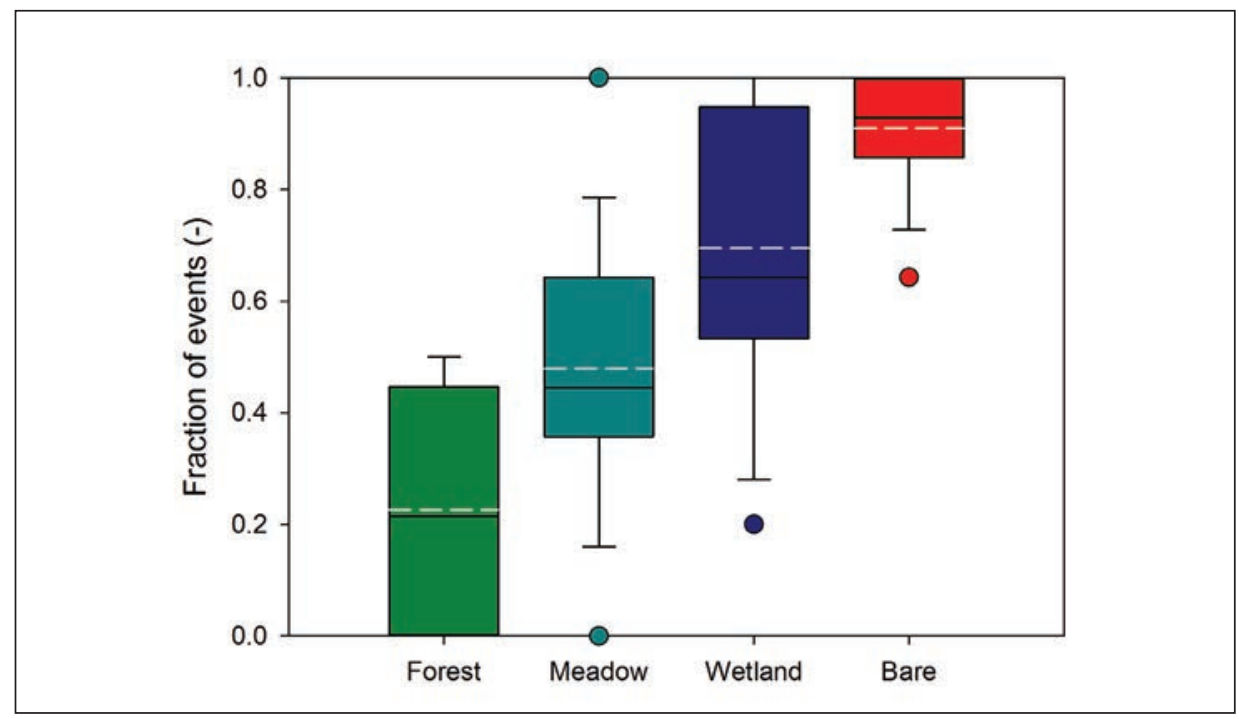

Figure 7. Box plots of the fraction of the events for which surface runoff was measured at the overland flow collectors installed in different land use areas (14 sampled events between August and October 2016). Six overland flow collectors were installed in the forest, 15 in the meadows, 15 in the wetlands and 14 in bare areas. The box indicates the $25^{\text {th }}$ and $50^{\text {th }}$ percentile, the solid line the median, the dashed line the mean, the whiskers the $10^{\text {th }}$ and $90^{\text {th }}$ percentile and the circles the outliers. Data from Sauter (2017). 


\section{Hydrochemical and isotope based results}

\subsection{Event and pre-event water contributions to streamflow}

Isotope hydrograph separation for the 13 rainfall events sampled by Fischer et al. (2017a) showed that the pre-event water contribution to streamflow is highly dependent on the amount of rainfall and little affected by rainfall intensity and antecedent conditions. Peak flow during rainfall events, with less than $40 \mathrm{~mm}$ of precipitation was dominated by pre-event water but during larger events, peak streamflow was dominated by event water (Fischer et al., 2017a). For example, pre-event water contributions to peak flow varied between 10 and 36\% during the $110 \mathrm{~mm}$ event on 24.09.2010 (range for five headwater catchments) and between 28 and 55\% during the $84 \mathrm{~mm}$ event on 29.06 .2011 (range for four headwater catchments), while for a $24 \mathrm{~mm}$ event on 18.09.2011, it varied between 51 and 60\% (range for five headwater catchments) (Fischer et al., 2017a).

Despite the distinct differences in catchment characteristics (Table 1; Fig. 1), the differences in peak event water contributions to streamflow for the sub-catchments were relatively small (Fischer et al., 2017a), and may in part be due to the spatial differences in rainfall and its isotopic composition (Fischer et al., 2017b). For large events with a large spatial variability in the isotopic composition of rainfall and a small difference between the event and pre-event water isotopic composition, the calculated minimum pre-event water fractions differed up to $60 \%$ when different rain samplers were used to represent the event water isotopic composition (Fischer et al., 2017b). The isotope hydrograph separation results for long events during which air temperatures decreased towards $0^{\circ} \mathrm{C}$ were also highly uncertain (Fischer et al., 2017a).

\subsection{Streamflow chemistry during baseflow conditions}

The variability in the hydrochemistry and isotopic composition of baseflow at the catchment outlets was generally small and not significant. However, the within catchment variability in stream chemistry during the three baseflow snapshot sampling campaigns was large (Fischer et al., 2015). DOC concentrations were much higher in the wetlands than in areas with other land uses. Calcium concentrations were highest in (deeper) groundwater. The stable isotope data (representing the water itself), the DOC and calcium data helped to identify the different end-members: an upper spring zone (above $1400 \mathrm{~m}$ a.s.l.), shallow groundwater, and wetlands (Fischer et al., 2015). Stream samples had a distinctly different isotopic and hydrochemical composition than the groundwater in the wetlands and suggested that despite these areas being water-logged, they did not contribute significantly to baseflow (Fischer et al., 2015). Instead, the isotopic and hydrochemical composition of baseflow was more similar to (deeper) groundwater and changed only slightly from the upper spring zone located near the water divide towards the catchment outlets, and therefore suggested that during baseflow conditions groundwater from the upper part of the catchment was the main contributor to total streamflow at the outlet (Fischer et al., 2015). However, very detailed measurements along one of the smaller streams in the upper parts of the Studibach (C5) during summer 2016 showed that water chemistry changed significantly over very short distances (Fig. 8) and indicated the contribution of low Electrical Conductivity (EC) (shallow) soil and groundwater to the stream (Grunder, 2017). 


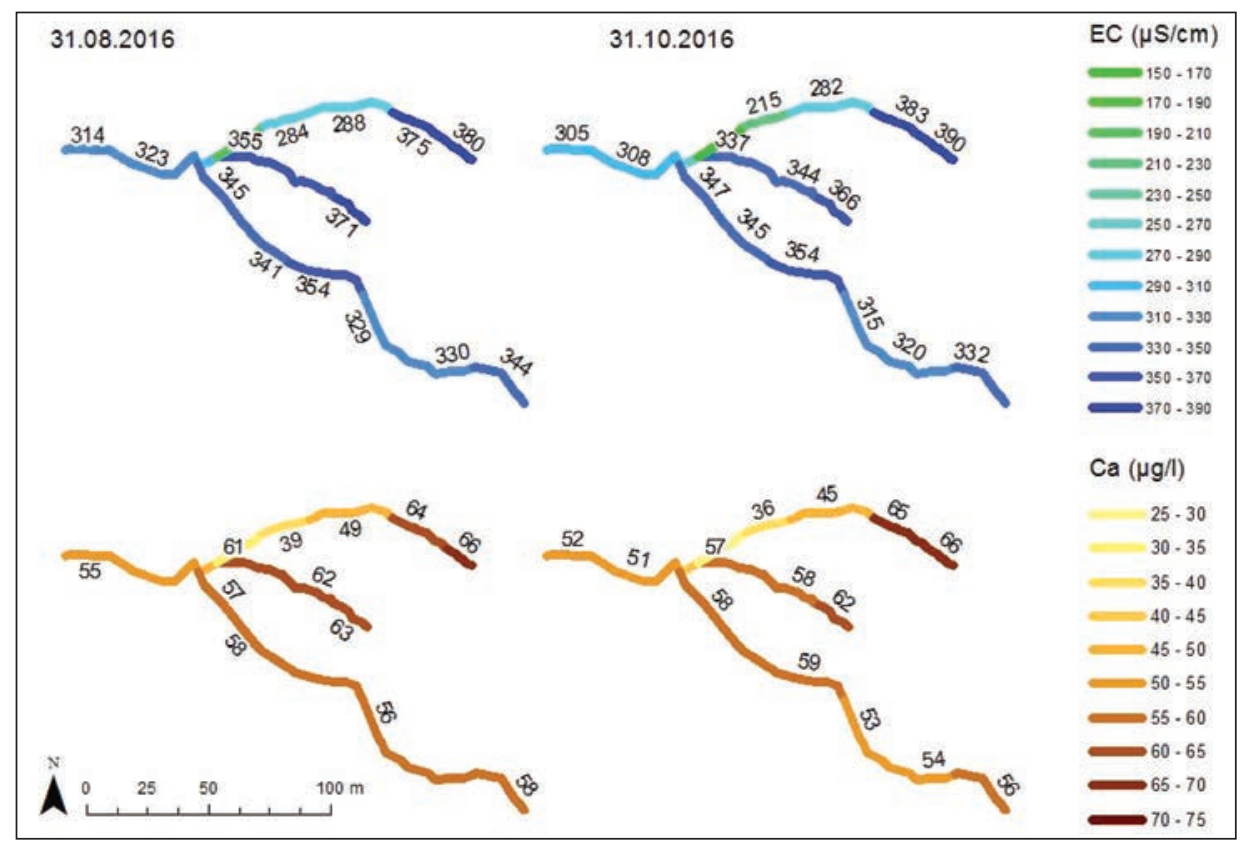

Figure 8. Electrical Conductivity (EC) and calcium concentrations $(\mathrm{Ca})$ of streamflow in the upper part of the Studibach (C5) on 31.08.2016 and 31.10.2016. Data from Grunder (2017).

\section{Discussion on the main runoff generation processes in the Alptal catchments}

Studying the hydrological processes using detailed hydrometric measurements in one headwater catchment (WS07), as well as observations from stable isotope responses during rainfall events and the spatial variability in hydrochemistry during baseflow conditions in multiple catchments allowed us to obtain a detailed understanding of runoff generation processes in the Alptal catchments. This understanding can be summarized as a discussion between a tracer hydrologist $(\mathrm{T})$ and a hydrologist focusing on the hydrometric observations $(\mathrm{H})$ on their perceptions on runoff generation processes in the Alptal catchments (Figs. 9 and 10).

T: Hi, I was searching for a lunch spot to sit down. However, everywhere I tried to sit down my trousers got wet immediately and with every step my boots were squeaking.

$\mathrm{H}$ : Nice to meet you out here! That is not strange because the Alptal catchments are wet throughout most of the year. This is due to the high clay content, the low drainable porosity and shallow soils. The water table is generally close to the soil surface, especially in hollows and flatter areas, where the hydraulic gradient is low (Fig. 10a, letter B) or at the bottom of hillslopes because of the large amount of water coming from upslope areas. (Fig. 10a, letter C). You could have found a dry lunch spot near the ridges (Fig. 10a, letter A), where the water table responds quickly to rainfall events but also declines within several days (Fig. 6). Surface soil moisture measurements also show that soil moisture is lowest in the forested ridge sites and highest in the flatter meadow and wetland sites. 


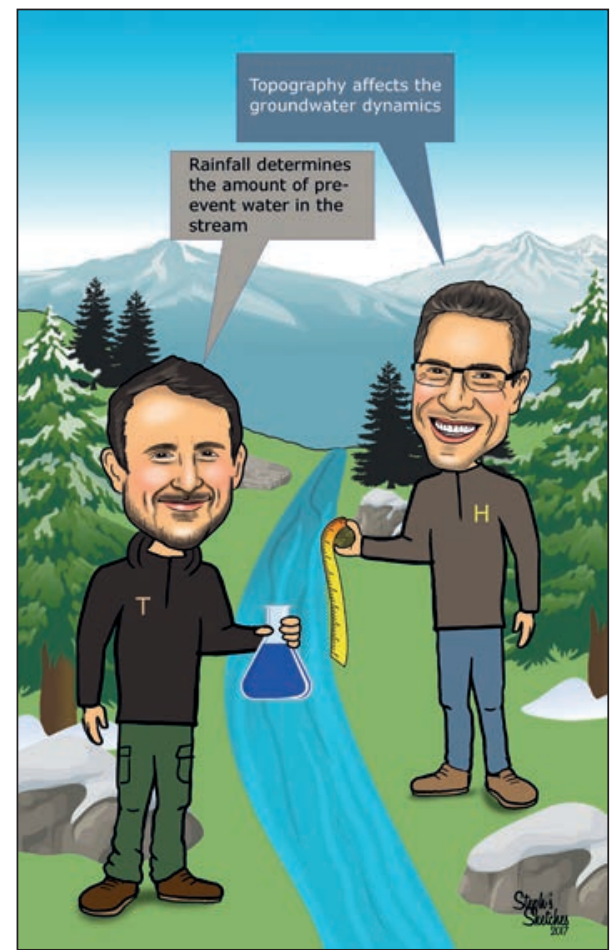

Figure 9. Discussion between two hydrologists in the field on their perspectives of the dominant runoff processes in the Alptal. One focuses on inferring hydrological processes from a tracer point of view $(T)$ and the other infers hydrological processes based on hydrometric measurements (H). Original drawing by Steph's sketches.

T: My data suggest that even though the groundwater level is high, the wetlands do not contribute to baseflow and are disconnected from the stream between events (Fig. $10 \mathrm{a}, \mathrm{nr}$ III). I don't see a clear signal from the wetland areas in the baseflow chemistry across the different catchments. Thus, water levels may not tell us which parts of the catchment contribute to streamflow.

$\mathrm{H}$ : Yes that is true, active areas (Ambroise, 2004) also need to be connected to the stream. During recessions, there is a good correlation between the shallow groundwater level and topography but during the longer dry spells that can occur in late autumn, the correlation decreases, which suggests that the upper hillslope and mid-slope locations become disconnected from the stream and likely don't contribute to streamflow. Hillslope studies in other countries have shown this disconnection of the hillslopes from the stream as well (Stieglitz et al., 2003; Ocampo et al., 2006; Jencso et al., 2009; Detty and McGuire, 2010; van Meerveld et al., 2015). I think that the wetlands near the stream are always connected to the stream but the connected area expands with increasing wetness conditions. So, topography really determines which areas are connected to the stream and contribute to streamflow. However, there is also a lot of variability in the groundwater responses, though not as much as in a study in southern Germany (Bachmair et al., 2012). The relation between 
topography and groundwater level responses only became clear when studying many wells and many rainfall events. The groundwater levels are most variable at the midslope, which suggests that they are key locations to understand catchment scale connectivity.

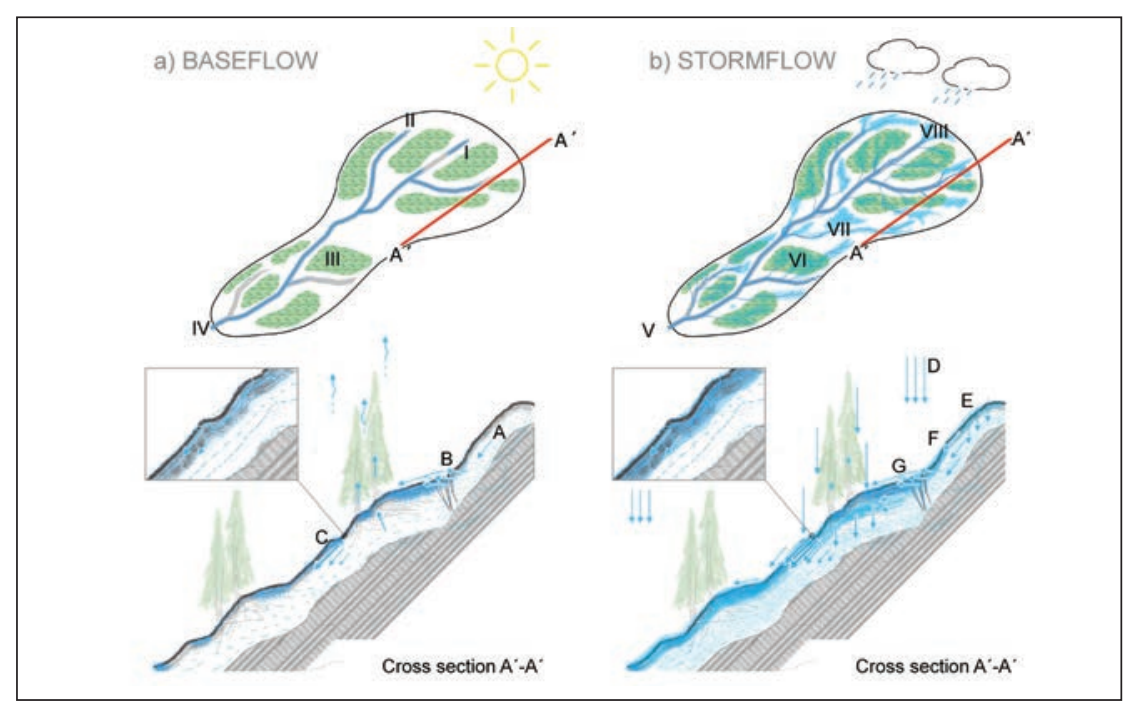

Figure 10. Conceptual model of hydrological processes in the Alptal catchments during baseflow conditions (a) and rainfall events (b). A plan view cross section is given in the top row, while the bottom row depicts a transect along the main slope of the catchment; the inserts show the near surface processes in more detail.

The letters and number refer to different processes and phenomena that are described in the text.

T: Near stream shallow groundwater may cause the dilution effect that I see in small stream segments. I found it really surprising that the EC of water can change significantly over such short distances (Fig. 8; Grunder, 2017). My snapshot sampling campaigns also showed a high variability in the chemical composition of baseflow within catchments, but there was no significant difference in the chemical composition of baseflow at the outlets of the catchments, even though the catchments have different land uses and geology (Table 1). This was not what I had expected based on the papers that I had read before I started my sampling (Likens and Buso, 2006; Asano et al., 2009; Zimmer et al., 2013). Another surprising thing that I learned from these sampling campaigns is that the springs located in the upper part of the catchment are the dominant source for baseflow (Fig. 10a, letter B and nr I and II). Isn't it interesting that despite their near-ridge location and, thus, relatively small upslope contributing area they largely continue to flow during dry periods and contribute such a large fraction of flow at the catchment outlet during baseflow conditions? (Fig. 10a, nr IV).

$\mathrm{H}$ : Yes, but even though some of these springs keep flowing during dry periods, we also see very large changes in the flowing stream network length (Sjöberg, 2015). So not only the upper hillslopes may become disconnected from the stream, and as you say the wetlands, but also different stream segments and thus parts of the catchment. At least these stream reaches are no longer connected by surface water flow, they may still be connected via subsurface flow. I read papers about the expansion and contraction of the flowing stream network in other places 
(Wigington et al., 2005; Godsey and Kirchner, 2014; Jensen et al., 2017) but it surprised me that in such a wet place as the Alptal, the flowing stream network is also so dynamic.

T: We should sample these intermittent streams to see if they are different and find out what causes the springs to flow.

H: Yes, certainly! You say that these upper catchment areas are responsible for almost half of the flow during baseflow conditions and that most of the baseflow is generated in the upper parts of the catchment. But the mean specific discharge and runoff ratios for the nested sub-catchments of the Studibach were correlated with sub-catchment area (Herrmann, 2014). This suggests that more stormflow is generated in the larger catchments. Even though these calculations are potentially affected by measurement errors, errors in the rating curve and errors related to the delineation of the catchment area, this suggests that soil and groundwater flow to the streams in the lower part of the catchment. I just read a paper from Japan where streamflow and runoff ratios increase with catchment size due to flow through the bedrock (Katsuyama et al., 2010). I found this interesting even though the bedrock in the Alptal is almost impermeable, so these results are not really comparable. But flysch is such a complicated material and perhaps there is some flow along more permeable layers with cracks and fissures that outcrop in the lower catchment. Who knows?

T: Well, the hydrochemical analysis of water samples taken along small sections of the stream channel and steady state tracer tests corroborate that flow likely increases along the stream, particularly at the steep stream sections (Grunder, 2017). This groundwater could also have a deeper component. How does groundwater respond to the frequent rainfall events?

$\mathrm{H}$ : The mean groundwater levels and the groundwater response timing were correlated with topographic indices. This suggests that groundwater levels in depressions and the footslopes are high and respond quickly (Fig. 10b, letter G). The ridge sides respond later and less frequently. This is similar to the effect of topography on groundwater level dynamics and the relation between groundwater levels and topography in other studies (Moore and Thompson, 1996; Seibert, 1997; Detty and McGuire, 2010), except that here the correlation between topography and groundwater levels is stronger. I think that this is due to the wet conditions and poorly permeable soils that lead to groundwater levels that are closer to the soil surface. The rise of the groundwater level into soil layers close to the soil surface with higher saturated hydraulic conductivity means that lateral, preferential flowpaths are activated and contribute water to the streams with only a short delay (Fig. 10b, letters E-G). Once lateral connectivity is established between the individual groundwater response areas and the channel network (Fig. 10b, number VII), the midslope areas also contribute to streamflow. Do your isotope data support this hypothesis?

T: I can't see the difference between lateral and vertical connectivity from my data at the catchment scale but the hydrograph separation results tell me that pre-event water is the main contributor to streamflow during small events and event water is important during large events (Fig. 10b, number V). The relation between event size and the new water fraction was also observed for a forested catchment in Italy (Penna et al., 2015). Because storage deficits are not satisfied during small events and distant parts of the catchment do not get connected to the stream, it isn't that surprising that the event water contributions are relatively small during small 
events. During these smaller events, the initial rise in streamflow is maybe not only generated by fast lateral flow from the hillslopes but the wetlands close to the streams also become more connected during events and also contribute pre-event water to streamflow (Fig. 10b, number VI and letters G-F). My results mainly show that rainfall characteristics, such as total rainfall, rainfall intensity and duration, are the dominant factors that determine the runoff response (Fischer et al., 2017a). The differences in the runoff response for the different catchments are not that large. This might be due to the frequent rainfall that overrides any differences in catchment characteristics and antecedent wetness conditions.

$\mathrm{H}:$...and the low permeability soils that drain slowly and cause high water tables to persist for a long time. Based on my data, I would say that shallow subsurface flow from the near stream areas likely occurs throughout the year but that the midslope and ridge sites only become active and connected during larger events. Overall, these results suggest that the contributing areas expand during rainfall events and that different areas of the catchment become connected and contribute to streamflow at different times. Groundwater will mainly deliver pre-event water to the stream but the preferential flow pathways in the near surface layers may deliver a mixture of event and pre-event water.

T: Dye tracer tests in the Vogelbach catchment by Weiler et al. (1999) showed that preferential flow can be a source of event water. I think that these shallow pathways may get flushed during large events.

$\mathrm{H}$ : Surface runoff also contributes some of the event water to the stream, although its isotopic composition and chemistry suggest that it is a mixture of event and preevent water (Sauter, 2017). Saturation overland flow from the meadows and wetlands is important during rainfall events. Infiltration excess overland flow occurs on the bare areas but likely infiltrates when it reaches the vegetated areas. So there are multiple runoff processes happening at the same time.

T: The long-term measurements by WSL already showed that these catchments respond really quickly to rainfall. I think that the combination of my tracer data and your detailed data on soils and groundwater responses has really helped us to better understand runoff generation processes in this area. This information is useful to develop hydrological models for this area.

$\mathrm{H}$ : Certainly, but there are also still some open questions related to which parts of the catchment are connected and contribute to streamflow and how much topography or landscape characteristics affect this. I am currently using the distance-based similarity measure (Rinderer et al., 2017) to cluster the groundwater data to obtain groundwater time series for every location in the catchment. I can use these to create maps of catchment scale groundwater level responses to study connectivity and investigate how connectivity affects the streamflow response. My initial results show that the areas where the groundwater responds and is connected to the stream are predominantly aligned with the channel network and that this area expands and contracts during events. But isolated areas with a groundwater response also connect to the stream network during the short periods of time that were associated with the highest streamflow (Rinderer et al., in preparation).

T: And did you hear about the new PhD students running around in our catchments? It will be interesting to see how the interplay of rainfall, topography and groundwater 
dynamics affects the groundwater chemistry and if we can use this knowledge to determine what parts of the catchment contribute to streamflow from the stream chemistry.

H: And there are probably many other things that still need to be discovered.

\section{Acknowledgements}

We thank all students, colleagues, friends and family members who have helped in the field, Ivan Woodhatch, Bruno Kägi, Claudia Schreiner, Sandra Röthlisberger and Michael Hilf for laboratory assistance, colleagues in Zurich, especially at ETH and WSL, for stimulating discussions, and the OAK, Gemeinde Alpthal, the Canton Schwyz, family Heinzer, Annagreth Schuler and Werni Ruhstaller for supporting our work.

\section{References}

Ambroise, B. 2004. Variable 'active' versus 'contributing' areas or periods: a necessary distinction. Hydrological Processes 18, 1149-1155. http://doi.org/10.1002/hyp.5536.

Asano, Y., Uchida, T., Mimasu, Y., Ohte, N. 2009. Spatial patterns of stream solute concentrations in a steep mountainous catchment with a homogeneous landscape. Water Resources Research 45, W10432. http://doi.org/10.1029/2008WR007466.

Bachmair, S., Weiler, M., Troch, P.A. 2012. Intercomparing hillslope hydrological dynamics: Spatio-temporal variability and vegetation cover effects. Water Resources Research 48 W05537. http://doi.org/10.1029/2011wr011196.

Badoux,A.,Turowski,J.M.,Mao,L.,Mathys,N.,Rickenmann,D.2012.Rainfall intensity-duration thresholds for bedload transport initiation in small Alpine watersheds. Natural Hazards and Earth System Sciences 12, 3091-3108. http://doi.org/10.5194/nhess-12-3091-2012.

Beven, K.J., Kirkby, M.J. 1979. A physically based, variable contributing area model of basin hydrology / Un modèle à base physique de zone d'appel variable de l'hydrologie du bassin versant. Hydrological Sciences Bulletin 24,43-69.http:doi.org/10.1080/02626667909491834.

Bonell, M., Fritsch, J. 1997. Combining hydrometric-hydrochemistry methods: a challenge for advancing runoff generation process research. In: N.E. Peters, A. Coudrain-Ribstein (Eds.), Hydrochemistry. IAHS Publication 244, 165-184.

Burch, H. 1994. Ein Rückblick auf die hydrologische Forschung der WSL im Alptal. Beiträge zur Hydrologie der Schweiz 35, 18-33.

Burch, H., Forster, F., Schleppi, P. 1996. Zum Einfluss des Waldes auf die Hydrologie der FlyschEinzugsgebiete des Alptals. Schweizerische Zeitschrift für Forstwesen 147, 925-938.

Carey, S.K., Quinton, W.L. 2005. Evaluating runoff generation during summer using hydrometric, stable isotope and hydrochemical methods in a discontinuous permafrost alpine catchment. Hydrological Processes 19, 95-114. http://doi.org/10.1002/hyp.5764.

Detty, J.M., McGuire, K.J. 2010. Topographic controls on shallow groundwater dynamics: implications of hydrologic connectivity between hillslopes and riparian zones in a till mantled catchment. Hydrological Processes 24, 2222-2236. http://doi.org/10.1002/hyp.7656.

Engler, A. 1919. Untersuchungen uber den Einfluss des Waldes auf den Stand der Gewasser. Mitteilungen der Schweizerischen Zentralanstalt fur das forstliche Versuchswesen 12, 1-626.

Feyen, H.M.J. 1998. Identification of runoff processes in catchments with a small scale topography. ETH Zurich, Nr. 12868, Zurich, 162 pp.

Fischer, B.M.C. 2016. Spatial and temporal runoff generation processes in a Swiss pre-alpine headwater catchment. Department of Geography, University of Zurich, Zurich, 134 pp. 
Fischer, B.M.C., Rinderer, M., Schneider, P., Ewen, T., Seibert, J. 2015. Contributing sources to baseflow in pre-alpine headwaters using spatial snapshot sampling. Hydrological Processes 29, 5321-5336. http://doi.org/10.1002/hyp.10529.

Fischer, B.M.C., Stähli, M., Seibert, J. 2017a. Pre-event water contributions to runoff events of different magnitude in pre-alpine headwaters. Hydrology Research 48, 28-47. http://doi. org/10.2166/nh.2016.176.

Fischer, B.M.C., van Meerveld, H.J., Seibert, J. 2017b. Spatial variability in the isotopic composition of rainfall in a small headwater catchment and its effect on hydrograph separation. Journal of Hydrology 547, 755-769. http://doi.org/10.1016/j.jhydrol.2017.01.045.

Godsey, S.E., Kirchner, J.W. 2014. Dynamic, discontinuous stream networks: hydrologically driven variations in active drainage density, flowing channels and stream order. Hydrological Processes 28, 5791-5803. http://doi.org/10.1002/hyp.10310.

Grunder, N.R. 2017. Spatial and temporal variability in streamflow chemistry in two small prealpine catchments. Department of Geography, University of Zurich, Zurich, $59 \mathrm{pp}$.

Hagedorn, F., Schleppi, P., Waldner, P., Flühler, H. 2000. Export of dissolved organic carbon and nitrogen from Gleysol dominated catchments - the significance of water flow paths. Biogeochemistry 50, 137-161. https://doi.org/10.1023/A:1006398105953.

Hagedorn, F., Schleppi, P., Bucher, J., Flühler, H. 2001. Retention and Leaching of Elevated N Deposition in a Forest Ecosystem with Gleysols. Water, Air, and Soil Pollution 129, 119-142.

Hantke, R. (Ed.) 1967. Geologische Karte des Kanton Zürich und seiner Nachbargebiete.

Hegg, C., McArdell, B.W., Badoux, A. 2006. One hundred years of mountain hydrology in Switzerland by the WSL. Hydrological Processes 20, 371-376. https://doi.org/10.1002/ hyp. 6055 .

Herrmann, P. 2014. Dynamik und Prozesse der Abflussbildung und Abflusskonzentration eines steilen voralpinen Einzugsgebiets im Alptal (SZ). Department of Geography, University of Zurich, Zurich, 87 pp.

Hsü, K.J., Briegel, U. 1991. Der Flysch. Geologie der Schweiz: Ein Lehrbuch für den Einstieg, und eine Auseinandersetzung mit den Experten. Birkhäuser Basel, Basel, pp. 65-82.

Jencso, K.G., McGlynn, B.L., Gooseff, M.N., Wondzell, S.M., Bencala, K.E., Marshall, L.A. 2009. Hydrologic connectivity between landscapes and streams: Transferring reach and plot scale understanding to the catchment scale. Water Resources Research. 45, W04428. http:// doi.org/04410.01029/02008WR007225.

Jensen, C.K., McGuire, K.J., Prince, P.S. 2017. Headwater stream length dynamics across four physiographic provinces of the Appalachian Highlands. Hydrological Processes 31, 33503363. http://doi.org/10.1002/hyp.11259.

Katsuyama, M., Tani, M., Nishimoto, S. 2010. Connection between streamwater mean residence time and bedrock groundwater recharge/discharge dynamics in weathered granite catchments. Hydrological Processes 24, 2287-2299. http://doi.org/10.1002/hyp.7741.

Keller, H.M. 1970. Factors affecting water quality of small mountain catchments. Journal of Hydrology (New Zealand) 9, 133-141.

Kollegger,A.A.2011. Untersuchung der räumlichen undzeitlichen Verteilung der Bodenfeuchtigkeit am Beispiel des Erlenbaches (Alptal/Schweiz) - Vergleich einer quantitativen und einer qualitativen Messmethode. Department of Geography, University of Zurich, Zurich, 83 pp.

Likens, G.E., Buso, D.C. 2006. Variation in Streamwater Chemistry Throughout the Hubbard Brook Valley. Biogeochemistry 78, 1-30. http//doi.org/10.1007/s10533-005-2024-2.

Mohn, J., Schürmann, A., Hagedorn, F., Schleppi, P., Bachofen, R. 2000. Increased rates of denitrification in nitrogen-treated forest soils. Forest Ecology and Management 137, 113 119. https://doi.org/10.1016/S0378-1127(99)00320-5. 
Molnar, P., Densmore, A.L., McArdell, B.W., Turowski, J.M., Burlando, P. 2010. Analysis of changes in the step-pool morphology and channel profile of a steep mountain stream following a large flood. Geomorphology 124, 85-94. http://doi.org/10.1016/j.geomorph.2010.08.014.

Moore, R.D., Thompson, J.C. 1996. Are Water Table Variations in a Shallow Forest Soil Consistent with the TOPMODEL Concept? Water Resources Research 32, 663-669. http://doi. org/10.1029/95WR03487.

Ocampo, C.J., Sivapalan, M., Oldham, C. 2006. Hydrological connectivity of upland-riparian zones in agricultural catchments: Implications for runoff generation and nitrate transport. Journal of Hydrology 331, 643-658. https://doi.org/10.1016/j.jhydrol.2006.06.010.

Penna, D., van Meerveld, H.J., Oliviero, O., Zuecco, G., Assendelft, R.S., Dalla Fontana, G., Borga, M. 2015. Seasonal changes in runoff generation in a small forested mountain catchment. Hydrological Processes 29, 2027-2042. http://doi.org/10.1002/hyp.10347.

Providoli, I., Bugmann, H., Siegwolf, R., Buchmann, N., Schleppi, P. 2006. Pathways and dynamics of $15 \mathrm{NO} 3-$ and $15 \mathrm{NH} 4+$ applied in a mountain Picea abies forest and in a nearby meadow in central Switzerland. Soil Biology and Biochemistry 38, 1645-1657. http://doi. org/10.1016/j.soilbio.2005.11.019.

Rickenmann, D., Turowski, J.M., Fritschi, B., Klaiber, A., Ludwig, A. 2012. Bedload transport measurements at the Erlenbach stream with geophones and automated basket samplers. Earth Surface Processes and Landforms 37, 1000-1011. http://doi.org/10.1002/esp.3225.

Rinderer, M. 2015. Patterns of groundwater and soil moisture variability: Hard data, soft data and dominant controls. Department of Geography, University of Zurich, Zurich, 124 pp. https:// doi.org/10.5167/uzh-120907.

Rinderer, M., van Meerveld, H.J., Seibert, J. 2014. Topographic controls on shallow groundwater levels in a steep, prealpine catchment: When are the TWI assumptions valid? Water Resources Research 50, 6067-6080. http://doi.org/10.1002/2013WR015009.

Rinderer, M., van Meerveld, I., Stähli, M., Seibert, J. 2016. Is groundwater response timing in a pre-alpine catchment controlled more by topography or by rainfall? Hydrological Processes 30, 1036-1051. http://doi.org/10.1002/hyp.10634.

Rinderer, M., McGlynn, B.L., van Meerveld, H.J. 2017. Groundwater similarity across a watershed derived from time-warped and flow-corrected time series. Water Resources Research 53, 3921-3940. http://doi.org/10.1002/2016WR019856.

Rinderer, M., van Meerveld, H.J., McGlynn, B.L. in preparation. From points to patterns - Using groundwater time series clustening to investigate subsurface hydrological connectivity and runoff source area dymanics.

Roth, D.L., Brodsky, E.E., Finnegan, N.J., Rickenmann, D., Turowski, J.M., Badoux, A. 2016. Bed load sediment transport inferred from seismic signals near a river. Journal of Geophysical Research: Earth Surface 121, 725-747. http://doi.org/10.1002/2015JF003782.

Sauter, T. 2017. Occurrence and chemical composition of overland flow in a pre-alpine catchment, Alptal $(\mathrm{CH})$. Department of Geography, University of Zurich, Zurich, 79 pp.

Schleppi, P., Muller, N., Feyen, H., Papritz, A., Bucher, J.B., Flühler, H. 1998. Nitrogen budgets of two small experimental forested catchments at Alptal, Switzerland. Forest Ecology and Management 101, 177-185. https://doi.org/10.1016/S0378-1127(97)00134-5.

Schleppi, P., Hagedorn, F., Providoli, I. 2004 . Nitrate Leaching From a Mountain Forest Ecosystem with Gleysols Subjected to Experimentally Increased N Deposition. Water, Air and Soil Pollution: Focus 4, 453-467. https://doi.org/10.1023/B:WAFO.0000028371.72044.fb.

Seibert, J., Bishop, K.H., Nyberg, L. 1997. A test of TOPMODEL's ability to predict spatially distributed groundwater levels. Hydrological Processes 11, 1131-1144. http://doi. org/10.1002/(SICI)1099-1085(199707)11:9<1131::AID-HYP549>3.0.CO;2-\#. 
Sjöberg, O. 2015. The Origin of Streams - Stream cartography in Swiss pre alpine headwater (Bäckarnas ursprung - Kartering över temporära bäckar i föralpina källområden i Schweiz). Department of Earth Sciences, Uppsala Universitet, Uppsala, 75 pp.

Smith, J.C., Galy, A., Hovius, N., Tye, A.M., Turowski, J.M., Schleppi, P. 2013. Runoff-driven export of particulate organic carbon from soil in temperate forested uplands. Earth and Planetary Science Letters 365, 198-208. https://doi.org/10.1016/j.eps1.2013.01.027.

Sodemann, H., Zubler, E. 2010. Seasonal and inter-annual variability of the moisture sources for Alpine precipitation during 1995-2002. International Journal of Climatology 30, 947-961. https://doi.org/10.1002/joc.1932.

Stähli, M., Gustafsson, D. 2006. Long-term investigations of the snow cover in a subalpine semiforested catchment. Hydrological Processes 20, 411-428. http://doi.org/10.1002/hyp.6058.

Stähli, M., Jonas, T., Gustafsson, D. 2009. The role of snow interception in winter-time radiation processes of a coniferous sub-alpine forest. Hydrological Processes 23, 2498-2512. http:// doi.org/ 10.1002/hyp.7180.

Stähli, M., Badoux, A., Ludwig, A., Steiner, K., Zappa, M., Hegg, C. 2011. One century of hydrological monitoring in two small catchments with different forest coverage. Environmental Monitoring and Assessment 174, 91-106. https://doi.org/10.1007/s10661-010-1757-0.

Stewart, M.K., Mehlhorn, J., Elliott, S. 2007. Hydrometric and natural tracer (oxygen-18, silica, tritium and sulphur hexafluoride) evidence for a dominant groundwater contribution to Pukemanga Stream, New Zealand. Hydrological Processes 21, 3340-3356. http://doi. org/10.1002/hyp.6557.

Stieglitz, M., Shaman, J., McNamara, J., Engel, V., Shanley, J., Kling, G.W. 2003. An approach to understanding hydrologic connectivity on the hillslope and the implications for nutrient transport. Global Biogeochemical Cycles 17, 1105. http://doi.org/1110.1029/2003GB002041.

van Meerveld, H.J., Seibert, J., Peters, N.E. 2015. Hillslope-riparian-stream connectivity and flow directions at the Panola Mountain Research Watershed. Hydrological Processes 29, 35563574. http://doi.org/10.1002/hyp.10508.

Weiler, M., Scherrer, S., Naef, F., Burlando, P. 1999. Hydrograph separation of runoff components based on measuring hydraulic state variables, tracer experiments, and weighting methods. IAHS Publication 258, 249-255.

Wenninger, J., Uhlenbrook, S., Lorentz, S., Leibundgut, C. 2008. Identification of runoff generation processes using combined hydrometric, tracer and geophysical methods in a headwater catchment in South Africa. Hydrological Sciences Journal 53, 65-80. http://doi.org/10.1623/ hysj.53.1.65.

Wigington, P.J., Moser, T.J., Lindeman, D.R. 2005. Stream network expansion: a riparian water quality factor. Hydrological Processes 19, 1715-1721. http://doi.org/10.1002/hyp.5866.

Wyss, C.R., Rickenmann, D., Fritschi, B., Turowski, J.M., Weitbrecht, V., Boes, R.M. 2016. Measuring bed load transport rates by grain-size fraction using the Swiss Plate Geophone signal at the Erlenbach. Journal of Hydraulic Engineering 142, 04016003. http://doi. org/10.1061/(ASCE)HY.1943-7900.0001090.

Zehnder, M. 2013. Hydraulic Conductivity Estimation and Analysis using Slug Tests - Relations with Site-Characteristics in a pre-alpine torrent catchment, Alptal (SZ). Department of Geography, University of Zurich, Zurich, 54 pp.

Zimmer, M.A., Bailey, S.W., McGuire, K.J., Bullen, T.D. 2013. Fine scale variations of surface water chemistry in an ephemeral to perennial drainage network. Hydrological Processes 27, 3438-3451. http://doi.org/10.1002/hyp.9449.

Zimmermann, B., Zimmermann, A., Turner, B.L., Francke, T., Elsenbeer, H. 2014. Connectivity of overland flow by drainage network expansion in a rain forest catchment. Water Resources Research 50, 1457-1473. http://doi.org/10.1002/ 2012WR012660. 